\title{
Mediji danas - Uvod u masovne komunikacije
}

\author{
Multimedia Clio, Beograd, 2012., 545 str.
}

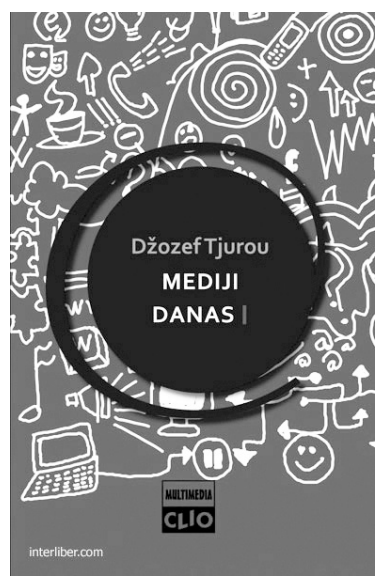

Knjiga Josepha Turowa Mediji danas - Uvod u masovne komunikacije u SAD-u je u izdanju Routledgea doživjela svoje četvrto izdanje. Beogradska izdavačka kuća Clio 2012. godine prevela je i objavila treće izdanje ove knjige. Joseph Turow je profesor komunikacija na Annenberg školi za komunikacije Sveučilišta u Pennsylvaniji, urednik je i autor brojnih knjiga i znanstvenih članaka o industriji masovnih medija. Knjiga Mediji danas - Uvod u masovne komunikacije podijeljena je na tri dijela. Prvi dio, Kako razumjeti prirodu masovnih medija, daje uvid u osnovne pojmove i objašnjava načine djelovanja medijske industrije a obuhvaća četiri poglavlja: Kako razumjeti masovne medije, Što je medijsko poslovanje, Formalne $i$ neformalne kontrole medijskih sadržaja: državna regulativa, samoregulativa i etika i Istraživanja medijskih učinaka i medijske kulture. Drugi dio, Medijski divovi i višemedijske aktivnosti, sadržajno je vezan uz velike medijske kompanije i sastoji se od dvaju poglavlja: Svijet nejasnih granica između medija i Strategije medijskih divova. Treći dio, Tiskani mediji, obuhvaća poglavlja Industrija knjiga, Industrija novina i Industrija časopisa i pobliže se bavi načinima funkcioniranja tiskanih medija. Na kraju knjige nalazi se popis pojmova po pojedinim poglavljima. Već je u predgovoru sam autor naznačio da je knjigu oblikovao kao udžbenik koji slijedi tijek jedinica osnovnog kolegija te da je namijenio prvenstveno studentima i nastavnicima medija (i to s područja SAD-a, sudeći prema određenim temama i primjerima kojima se bavi). Na početku svakog poglavlja naveden je neki citat koji bi trebao poslužiti kao poticaj za razmišljanje i raspravu o određenom problemu ili pojavi. Na kraju poglavlja nalaze se pitanja za diskusiju i kritičko razmišljanje te zadaci za izgradnju medijske pismenosti, a tekst je obogaćen brojnim prilozima o aktualnim pojavama vezanim uz medije, etičkim pitanjima, utjecajima na kulturu, primjerima iz svakodnevnog života, rezultatima znanstvenih istraživanja, medijskim ličnostima i sl. te slikama i tablicama koje prate sadržaj teksta. Četiri su osnovna koncepta na kojima je knjiga oblikovana: shvaćanje medija kao međusobno povezanih sustava industrija, uvid u temeljne pravce kretanja medija, naglasak na digitalnoj konvergenciji i medijsko opismenjavanje studenata kao osnovni cilj.

U prvom poglavlju, Kako razumjeti prirodu masovnih medija, Turow se opredjeljuje za uporabu pojma masovne komunikacije, iako se neki teoretičari zalažu za 
odustajanje od njega budući da je odrednica masovnosti dovedena u pitanje pojavom usitnjavanja i fragmentacije publike. Međutim imanentno je obilježje procesa industrijalizirane proizvodnje i distribucije poruka putem tehnoloških uređaja, koji predstavlja definiciju masovnih komunikacija, potencijal istovremenog doticaja $s$ ogromnim brojem ljudi, pa autor smatra da se od ovog pojma ne treba odustati. U ovom poglavlju autor je pobliže objasnio temeljne pojmove kao što su komunikacija, poruka, elementi komunikacije, mediji i njihov odnos prema kulturi. Odmah naglašava i tvrdnju da su medijski proizvodi roba čija je produkcija slična industrijskoj proizvodnji ostalih dobara i da ljudi na različite načine koriste medije (polazeći ovdje od teorije zadovoljenja potreba), i to za uživanje, druženje, praćenje i tumačenje. Uloga je masovnih medija trostruka: ukazuju nam na to što je prihvatljivo, a što nije, upoznaju nas sa značajnim osobama i njihovom ulogom i sugeriraju nam, budući da predstavljaju jedan aspekt poopćenog drugog, što drugi misle o nama i što bismo mi trebali misliti o drugima. Prvo poglavlje autor završava navodeći temeljne principe koje studenti trebaju usvojiti na svom putu do medijske pismenosti (65. str.): 1. medijski se materijali izgrađuju i predstavljaju svojevrsni konstrukt, a ne stvarnost; 2. oni su uronjeni u komercijalno okruženje; 3. uronjeni su u političko okružje; 4. osnovni su im oblici zabava, vijesti, informacija, obrazovanje i oglasi; 5. ljudi su aktivni recipijenti medijskih sadržaja, pa 6. u velikoj mjeri na temelju njih izgrađuju svoje viđenje stvarnosti. Uz temeljne principe valja usvojiti i određene vještine (sposobnost uočavanja utjecaja komercijalnih i političkih sila koje stoje u pozadini medijskih sadržaja, sposobnost uočavanja etičkih implikacija unutar medijske produkcije, sposobnost uočavanja utjecaja publike na medije i utjecaja medija na pojedinca i društvo...) kako bi pojedinac bio medijski pismen, odnosno kritičan potrošač medijskih materijala.

U drugom poglavlju, Što je medijsko poslovanje, Turow najprije nastoji prikazati publiku onako kako je vidi medijska industrija. Naime, oni pod imperativom zarade nastoje privući što više oglašivača, pa na publiku gledaju prije svega kao na potrošače. Nerijetko i okreću redoslijed pa polaze od ciljne publike određenih oglašivača te je određenim, upravo za nju oblikovanim sadržajima nastoje i privući. Kako bi u tome bile što uspješnije, mnoge medijske kompanije skupljaju demografske podatke o publici ili provode istraživanja koja se temelje na psihografiji ili istraživanju životnih navika. Turow ovdje ukazuje i na djelatnost kompanija čiji je osnovni zadatak skupljanje informacija iz raznih izvora i sastavljanje baza podataka o pojedinim osobama koje onda prodaju medijskim ili drugim kompanijama zainteresiranima za plasiranje svojih proizvoda. Medijska industrija i svoj sadržaj oblikuje tako da privuče određenu publiku. Osnovne su kategorije medijskih sadržaja zabava, vijesti, informacije, obrazovanje i oglasi. Autor dalje opisuje svaki od ovih žanrova dajući recentne primjere i dijeleći ih na podžanrove. U drugom dijelu poglavlja prikazan je proces proizvodnje, distribucije i izlaganja medijskih proizvoda. U procesu proizvodnje sudjeluje administrativno i kreativno osoblje a proizvod može biti pojedinačno djelo, ali i format, odnosno unaprijed određeni raspored medijskog materijala. Distribucija označava transfer proizvedenog materijala do mjesta na kojemu će biti izložen i ponuđen publici. Financiranje sadržaja masovnih medija dijeli se na dvije kategorije, financiranje nove proizvodnje (odnosi se na kreditno zaduživanje i emisiju i prodaju dionica) i financiranje gotovog proizvoda (neposrednom proda- 
jom, prodajom licenci, iznajmljivanjem, naplatom korištenja, pretplatom i oglasima). Poglavlje Formalne $i$ neformalne kontrole medijskih sadržaja: državna regulativa, samoregulativa $i$ etika upoznaje čitatelje s načinima na koje se reguliraju medijski sadržaji. Autor razlikuje četiri idealtipa državne regulative medija: autoritarni, komunistički, društveno odgovorni i slobodnjački te se detaljno bavi Prvim amandmanom Ustava SAD-a i načinima njegove provedbe u praksi. Isto tako daje pregled i praktične primjere američkih regulativa koje, unatoč Prvom amandmanu, ograničavaju medijski sadržaj, i to prije njegove distribucije, poslije njegove distribucije i u sferi ekonomskog djelovanja medijskih kompanija. Činjenica je, prema Turowu, da su, iako su im mogućnosti kontrole govora uvelike ograničene Ustavom, vladini službenici skloni sprječavanju novinara u njihovoj namjeri da dođu do određenih informacija (181. str.). Zakoni koji su doneseni u drugoj polovici 20. st. (zakon o slobodi informacija, zakoni o slobodnom pristupu informacijama i zakoni koji štite novinare u izdavanju povjerljivih izvora) imaju za cilj ograničiti takve pojave. Osim formalne regulative, medijsko djelovanje oblikuje se i pritiscima dijela javnosti, grupa građana i oglašivača. Kako bi izbjegli vanjske pritiske, formalne i neformalne, provodi se medijsko samouređivanje, i to kroz artikulaciju uređivačkih standarda, profesionalnih etičkih kodeksa, ocjena sadržaja, kategorizaciju medijskih materijala, osnivanje odjela odnosa s javnošću itd. Poglavlje autor završava kratkim pregledom najvažnijih etičkih postulata (zlatne sredine, zlatnog pravila, kategoričkog imperativa, principa korisnosti i vela neznanja) i njihovog značenja u medijskom djelovanju.

Četvrto poglavlje, Istraživanje medijskib učinaka i medijske kulture, donosi pregled znanstvenih teorija koje su se bavile istraživanjem medija, počevši od Čikaške škole čiji su pripadnici (Park, Cooley, Dewey) pisali o integrativnoj funkciji medija i njihovim pozitivnim učincima na društvo masa. U isto vrijeme javljaju se i teoretičari koji u medijima vide nositelja propagande moćnih interesnih grupa (Lasswell, Doob, McLang Lee) ili iskrivljenu sliku svijeta koju stvaraju sami novinari nametanjem tema (Lippmann). Istraživanja tzv. „Payneovog fonda“ pod nazivom Filmovi i mladi koja je provodio Charters ističu kako reakcije mladih na filmove ovise o nizu društvenih i psiholoških osobina pojedinca. Zabrinutost zbog negativnih utjecaja medija na pojedinca donekle su ublažila i istraživanja Mertona i Lazarsfelda, znanstvenika sa Sveučilišta Columbia, koji su svojim modelom dvostupanjskog protoka nastojali dokazati da ljudi nisu tek pasivni primatelji medijskih sadržaja, nego da ih aktivno interpretiraju ovisno o svojim interesima, osobinama i društvenim vezama. Mertonov i Lazarsfeldov rad imao je velikog utjecaja na kasniji razvoj teorije zadovoljenja potreba (uses and gratification theory) koja tvrdi kako ljudi aktivno koriste odredene medije za zadovoljavanje određenih potreba. Potvrdu da mediji imaju ograničen utjecaj na pojedinca nastojao je dati i Hovland, psiholog koji je na Sveučilištu Yale proveo niz istraživanja o utjecaju propagandnih filmova na studente. Njegov je zaključak da masovni mediji u normalnim uvjetima imaju vrlo ograničen učinak na promjenu stavova i ponašanja pojedinaca. Ovim dominantnim teorijama suprotstavlja se kritička teorija (Frankfurtska škola, istraživanja političke ekonomije i studije obrade) čiji su glavni argumenti da se medije treba promatrati kao čimbenike održavanja postojećeg stanja u društvu i da naglasak ipak treba staviti na šire društvene strukture koje posjeduju vlast i društvenu moć, a ne na pojedinca. 
Drugi dio knjige započinje poglavljem Svijet nejasnih granica između medija. Autor ističe šest međusobno isprepletenih pojava koje oblikuju masovne medije. To su usitnjavanje medija (porast broja masovnih medija koji uzrokuje osipanje publike koja koristi određeni medij), dijeljenje publike (prema određenim osobinama kako bi im se dostavile poruke i oglasi usmjereni posebno za njih), distribucija proizvoda preko granica među medijima (kako bi se uvećala zarada i što veći dio ciljne publike upoznao s postojanjem određenog medijskog sadržaja), globalizacija (medijski se materijali distribuiraju diljem svijeta, pa se unatoč osipanju publike zadržava njezina masovnost, a načini na koje se to postiže su stvaranje globalnih kompanija, koprodukcija i preuzimanje materijala iz zemljopisno udaljenih krajeva), stvaranje konglomerata (odnosno horizontalno povezivanje medijskih kompanija koje onda zajednički djeluju i prilagođavaju se lokalnim prilikama na globalnoj razini) i digitalna konvergencija (označava pretvaranje medijskih sadržaja u digitalne formate kako bi ih mogli koristiti različiti mediji). Turow ističe i kako u SAD-u nema posebnih zakonskih prepreka stvaranju konglomerata jer se nastoji očuvati domaći primat u svijetu masovnih medija. Međutim opasnosti koje se mogu pojaviti rastom konglomerata jesu u prvom planu ograničavanje tema kojima se mediji bave (tema moći korporacija nije poželjna, a manjine i žene isključeni su iz vlasničkih udjela radio-televizijskih ustanova u SAD-u), opasnost od komercijalizacije i homogenizacije sadržaja i ugrožavanje temeljnih demokratskih procesa (siva zona koja se otvara suradnjom političara i medijskih kompanija).

U šestom poglavlju, Strategije medijskih divova, Turow čitateljima daje uvid u način funkcioniranja triju medijskih konglomerata koji imaju ogroman utjecaj u svijetu medija, ali istovremeno i različite pristupe prethodno opisanim dominantnim tendencijama razvoja masovnih medija. Odabrani su konglomerati Walt Disney, News Corporation i Google. Razlike među njima vidljive su najprije iz strateških pravaca razvoja. Disneyjeva tri glavna strateška pravca su što više koristiti sinergiju dijelova kompanije (odnosno distribuciju proizvoda između različitih medija u vlasništvu kompanije), potaknuti globalno širenje materijala i usvojiti nove tehnologije digitalne distribucije kako bi njegovi proizvodi što jednostavnije došli do publike pazeći pri tome na opasnost od piratizacije. News Corporation svoje strategije vidi u brzom širenju na internetu i drugim digitalnim područjima te razvoju globalnih kanala distribucije koji su pod potpunom kontrolom korporacije. Turow tvrdi da ova kompanija stavlja izuzetno veliki naglasak na distribuciju (za razliku od Disneya kojemu je naglasak na sadržaju). Treća je strategija isticanje zabavnih sadržaja, vijesti i sporta, posebno onih sadržaja koji su popularni u ovim kategorijama, i njihova distribucija svim kanalima. Ipak, valja napomenuti da je od razdoblja kad je nastao tekst ove knjige News Corporation doživio velike promjene uslijed velikog skandala u koji je bio upleten njegov predsjednik i idejni začetnik Rupert Murdoch. Posljednja analizirana korporacija je Google. Njezine su glavne strategije daljnje poboljšanje privlačnosti sustava pretraživanja (uvodeći posebne usluge kao što su Google Scholar, Google Earth, Google Translator, ali i njihov interface koji postoji na 116 jezika), širenje oglasnih aktivnosti na druge medije i stvaranje drugih usluga koji će navesti korisnike da se uvijek vraćaju Googleu (npr. Gmail, Spreadsheets). 
Posljednji dio knjige pobliže se bavi tiskanim medijima. Sedmo poglavlje, Industrija knjiga, započinje povijesnim pregledom razvoja knjige kao medija te uvodi podjelu na stručne i obrazovne knjige s jedne strane, i knjige za široku publiku s druge. Izdavaštvo knjiga uključuje pronalaženje, pripremanje, oglašavanje, distribuciju i izlaganje knjige na mjestu gdje će je potrošač kupiti. Autor ističe kako se velika promjena u industriji knjiga može očekivati uslijed digitalizacije ovog medija, međutim teško da će knjige u svom originalnom obliku nestati. Brojna su etička pitanja i zamke prisutni u procesu pronalaženja autora knjiga za tisak, ali i u realizaciji i razvoju ideje djela (pitanje plagijata). Kako bi se smanjio rizik od neuspjeha izdane knjige, izdavači provode istraživanja prije objave materijala, teže izdavanju autora koji su već imali uspješne naslove i nude autorima avans na račun tantijema. Distribucija knjiga uglavnom se odvija preko veleprodajnih knjižarskih lanaca koji ih onda nude kupcima u svojim knjižarama ili preko internetskih stranica.

Osmo poglavlje, Industrija novina, daje pregled povijesnog razvoja novina. Revolucija u izdavaštvu novina dogodila se u prvoj polovici 19. st. kad je tehnologija tiskanja novina doživjela veliki razvojni skok uvođenjem parne tiskarske preše i razvojem izrade jeftinog papira, što je uz znatno smanjenu cijenu primjerka umnogostručilo prodaju. Novine se tako pretvaraju u industriju kojoj je osnovni cilj privući što više čitatelja, a financiranje se u najvećem dijelu počinje odvijati putem oglasa. S vremenom broj čitatelja novina počeo je sve više opadati (zbog konkurencije radija, televizije, interneta i pojave besplatnih novina) čemu se nastojalo doskočiti izdavanjem usko specijaliziranih novina, izdavanjem novina u boji, stvaranjem rubrika koje bi bile privlačne čitateljima, pojačavanjem lokalnih vijesti i sl. Međutim istraživanja pokazuju da mladi sve manje čitaju novine, pa tiraže i dalje padaju. Novine se tako manje financiraju prodajom izdanja, a više oglasima (koji čine u prosjeku 80\% prihoda dnevnih novina). Sve veću popularnost doživljavaju digitalne novine koje nastoje u novi medij prebaciti sadržaj klasičnih novina.

Industrija časopisa posljednje je poglavlje knjige. Kao i u prethodnim poglavljima, Turow najprije daje povijesni pregled razvoja časopisa i dijeli ih na pet kategorija: stručni časopisi, časopisi opće namjene, književni i znanstveni časopisi, bilteni i stripovi. Časopisi se uglavnom financiraju putem oglasa (osim biltena i znanstvenih časopisa koji se financiraju prodajom). Osnovni ciljevi svakog časopisa su, prema Turowu, privući odgovarajuću publiku (ovisno o oglašivačima) i prometnuti se u robnu marku koju će prepoznati i publika i oglašivači kako bi se mogli s njom poistovjetiti i izvan časopisa kao medija. Kritičari ističu da je proces konglomeracije na tržištu časopisa ugrozio male izdavače, a da oglašivači imaju preveliki utjecaj na sadržaj i da nisu uvijek jasne granice između novinarskog i oglasnog dijela.

Joseph Turow u ovoj je knjizi dao vrlo opširan, ali i pregledan uvid u način funkcioniranja svijeta masovnih medija, pa ona predstavlja iznimno korisnu literaturu svima koji se njime bave.

Nikolina Hazdovac Bajić 